Кондрацька Н. М., к.е.н., доцент Дзюба В. І., студент (Національний університет водного господарства та природокористування, м. Рівне)

\title{
ДЕРЖАВНИЙ БОРГ УКРАЇНИ: СТРУКТУРА, ДИНАМІКА ТА НАПРЯМИ ЙОГО МІНІМІЗАЦІї
}

У статті проведено аналіз динаміки та структури державного боргу протягом основних періодів розвитку держави. Обґрунтовано доцільність виділення нового періоду - пришвидшеного зростання державного бору. Виділено основні загрози в управлінні державним боргом та запропоновано ряд заходів, спрямованих на розбудову системи управління державним боргом, серед яких: оптимізація структури державного боргу, розвиток ринку державних цінних паперів, макроекономічного та бюджетного планування та прогнозування, оцінки та мінімізації фіскальних ризиків.

Ключові слова: державний борг, державні позики, зовнішні запозичення, внутрішні запозичення, боргова політика, структура держаBного боргу.

Вступ. Державний борг виступає важливою складовою економіки. Сьогодні важко знайти державу, яка була б спроможна обходитися без зовнішніх чи внутрішніх запозичень. Використання державою позик зумовлено нестачею власних фінансових ресурсів, необхідних для забезпечення виконання, покладених на неї функцій. За умови ефективного використання залучені кошти можуть стати позитивним чинником економічного зростання, але в іншому випадку збільшення заборгованості призводить до фінансової кризи, порушення макроекономічної стабільності.

Актуальність. На сьогодні проблема пошуку оптимальної структури державного боргу та його мінімізації, особливо в сучасних умовах, $є$ однією з основних у сфері бюджетно-фінансових відносин. Враховуючи сучасний економічний стан, залежність від зовнішнього кредитування та перспективу довгих років повернення отриманих коштів, питання удосконалення управління державним боргом $€$ актуальним та надзвичайно важливим. Вже тривалий час, у зв'язку з політичною та економічною нестабільністю, кризовими процесами, надмірними зовнішніми запозиченнями, в Україні спостерігаються перевищення безпечних та граничних показників державного боргу. Подальший соціально-економічний розвиток держави неможливий 
без удосконалення боргової політики держави. Теоретикометодологічні основи управління державним боргом досліджували такі науковці, як Ю. В. Пасічник, О. Царук, А. Сігайов, Серед представників класичної теорії державний борг вивчали В.Бютер, Дж. М. Кейнс, Т. Мальтус, Ф. Небеніум, Д. Рікардо, А. Сміт, А. Тана та ін.

Метою статті $\epsilon$ аналіз динаміки та структури державного боргу, пошук шляхів для удосконалення боргової політики держави в умовах кризи.

Основна частина. Як відомо, формування державного боргу $є$ невід'ємною складовою функціонування економіки та дієвим інструментом макроекономічного регулювання. Якісні та кількісні характеристики формування боргу суттєво залежать від макроекономічних та макрофінансових процесів в країні. Відповідно до динаміки основних індикаторів В. В. Лісовенко, Л. Я. Бенч, О. І. Бец виділили три основні періоди формування державного боргу України: 1991-1996рр. економічний спад; 1997-2007 рр. - порівняна макроекономічна стабілізація в окремих сегментах економіки й фінансів; 2008-2015рр. фінансово-економічна криза та посткризовий період [1, С. 20]. Розвиваючи дане дослідження, ми можемо додати ще один етап - 20152018 рр. - прискореного зростання державного боргу.

Розглянемо динаміку основних показників держаного боргу на кожному з етапів більш детально. Так, у 1995 р. почалась співпраця України з міжнародними фінансовими інституціями (МФІ), насамперед з Міжнародним валютним фондом (МВФ), Міжнародним банком реконструкції та розвитку (МБРР) та Європейським банком реконструкції та розвитку (ЄБРР). За рахунок кредитів від цих організацій зовнішній борг вже в 1996 р. зріс до 8,8 млрд дол. і склав 80\% державного боргу.

Паралельно започатковано випуск ОВДП для внутрішніх запозичень, які мали надвисоку прибутковість (40-60\% річних) і сприяли подальшому нарощенню боргу. Після впровадження гривні у 19962000 рр. державний борг продовжував зростати, а його джерела диверсифікуватися, що призвело до поступового нарощування комерційної складової боргу (ОЗДП, єврооблігації, державні гарантії, позики іноземних установ) і, відповідно, зменшення частки офіційного боргу, тобто боргу перед іноземними державами та міжнародними організаціями.

У 2000-2004 рр. проводилась більш виважена боргова політика, що було зумовлено неспроможністю погашення значних боргів. У цей період було проведено масштабну реструктуризацію запозичень та переглянуто принципи відносин із міжнародними кредиторами, співпраця з МФІ практично припинилася, сформовано ринок 
внутрішніх державних запозичень. Як наслідок, у 2004-2005 рр. борговий тиск на економіку зменшився, кредитний рейтинг України підвищився до В+ зі стабільним та позитивним прогнозом. Україна отримала доступ до міжнародних фондових ринків і почала розміщувати єврооблігації за ставками 7-9\% річних. Кон'юнктура світового ринку сировини була сприятливою, що дозволило значно знизити частку боргу у ВВП.

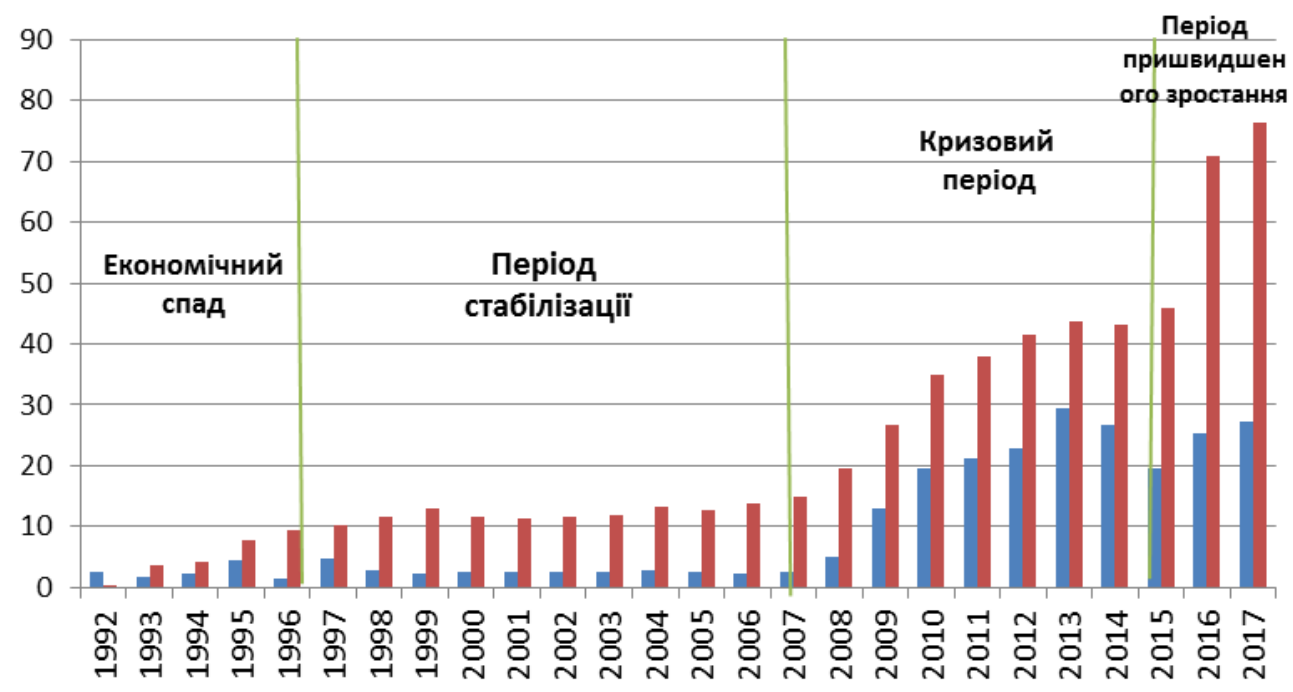

Борг номінований у національній валюті

Рис. 1. Динаміка державного боргу по валютах

Водночас в країну почав приходити іноземний спекулятивний капітал, збільшувалися обсяги споживчого кредитування та валютного кредитування ринку нерухомості, дефіцит платіжного балансу. Під час світової фінансової кризи 2008-2009 рр. Україна знову стала залежною від кредитування МФІ, а запозичені кошти спрямовувалися на фінансування поточних видатків. Водночас швидко зростав і внутрішній борг: лише в 2008 р. він збільшився з 5,8 млрд дол. до 17,8 млрд дол. Зовнішні запозичення на міжнародних ринках капіталів були легкодоступними для України в умовах сприятливої кон'юнктури, коли в них не було гострої потреби. Натомість під час кризових явищ (2000-2002 рр., 2008-2010 рр., 2013-2015 рр.), коли зовнішнє фінансування було вкрай необхідним, доступ до міжнародних фінансових ринків обмежувався, істотно зростали ризики рефінансування боргів. Варто зазначити, що для зменшення зовнішніх боргів уряд розробив Середньострокову стратегію управління державним боргом на 2013-2015 рр. Проте в умовах економічних диспропорцій, відсутності сильного реального сектора економіки та кри- 
зового стану фінансового ринку нові запозичення практично повністю спрямовувалися на погашення боргів попередніх періодів. Ситуація значно погіршилась у 2014-2018рр. Через бойові дії на сході країни та девальвацію гривні, в результаті якої зовнішній борг у гривневому еквіваленті у 2017 році зріс на 2,9 млрд дол. США і на кінець 2017 року становив 116,6 млрд дол. США. Відносно ВВП обсяг боргу скоротився за рік з 121,9\% до 106,4\%.

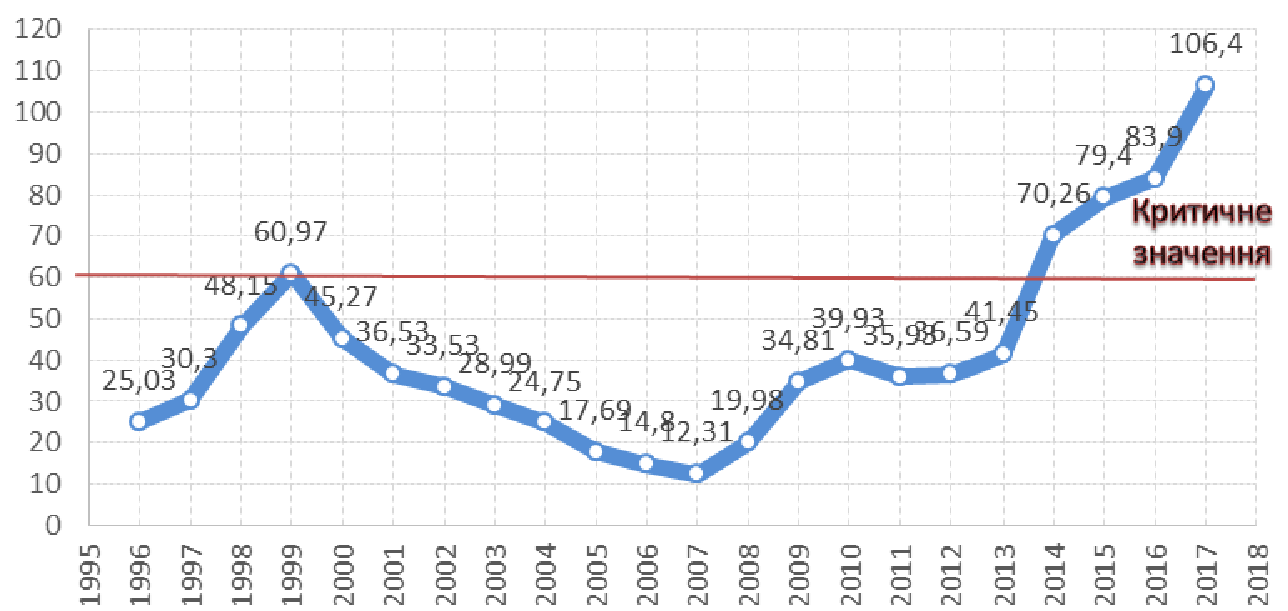

Рис. 2. Державний та гарантований державою борг у \% до ВВП

Внаслідок усіх перерахованих процесів, у 2017-2018 р. Україна мала надмірне боргове навантаження переважно через зовнішні запозичення, критичний показник боргу відносно ВВП та тенденції до зростання зовнішнього боргу, зниження можливостей його обслуговування, що свідчить про гостру необхідність вживання заходів 3 удосконалення боргової політики, мінімізації боргу та посилення економіки України [3, С. 385].

За результатами емпіричного дослідження ОЕСР граничний рівень державного боргу для країн з ринками, що формуються, складає $30-50 \%$ ВВП, а для розвинутих країн - 70-90\% ВВП. Проте ці значення розраховані для країн із середніми та низькими доходами, які мають доступ до залучення капіталу фінансових ринків за нормальними ринковими ставками. На жаль, Україна не має такого доступу, а отже, доцільно застосовувати граничну ставку на рівні 30-50\% [6]. Крім того, валовий зовнішній борг України, який включає як державний, так і корпоративні борги, у 2017 році складав 217,6\% експорту, в той час як гранично допустиме значення для країн з низькими і середніми доходами становить $200 \%$ експорту.

Варто відзначити, що найбільші виплати за держборгом мають відбутися у розпал президентської і парламентської виборчих кам- 
паній. Протягом 2018-2019 рр. уряд повинен повернути кредиторам 590 млрд грн, з яких 253,7 млрд грн, або близько 8,5 млрд дол., буде направлено на погашення та обслуговування зовнішніх позик. До речі, частина внутрішніх позик також номінована у валюті. У 2017 році основні витрати на виплату держборгу становитимуть: погашення 121,1 млрд грн внутрішнього боргу, а також повернення майже 1,5 млрд дол. МВФ. На сплату відсоткових нарахувань за боргами влада цього року запланувала понад 77 млрд грн за внутрішніми зобов'язаннями - переважно це обслуговування облігацій внутрішньої держпозики (ОВДП) і 45 млрд грн - за зовнішніми. Отже, під час виборчих кампаній виплати за внутрішнім боргом скоротяться, але уряд розраховуватиметься з МВФ і почне погашати єврооблігації, реструктурованих у 2015 р. Одночасно, уряд має виплатити 1 млрд дол. за євробондами, випущеними у 2014 р. під гарантії США. Більше того, у наступні два роки після виборів сума виплат все ще буде досить великою, особливо за зовнішніми позиками.

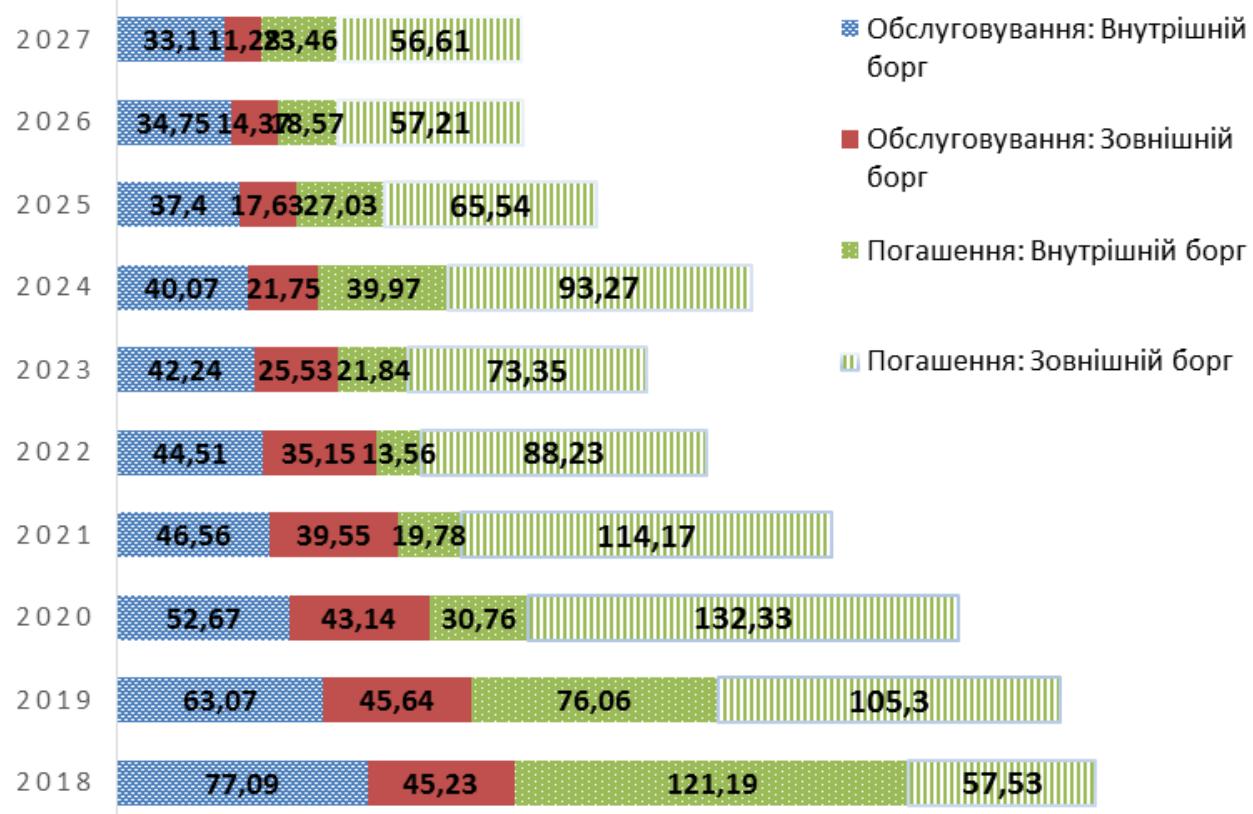

Рис. 3. Виплати за державним боргом у наступні 10 років, млрд грн

На короткострокову перспективу в Міністерства фінансів є два завдання - скоротити співвідношення валютних і гривневих боргів, щоб нівелювати девальваційні ризики, а також вийти на зовнішні ринки, щоб рефінансувати валютну заборгованість. Як відомо, уряд планує залучити цього року близько 3 млрд дол. зовнішніх позик. Приводом для такого прогнозу є те, що при розміщенні євробондів у вересні 2017 р. надійшло заявок більш ніж на 9 млрд дол. Проте від- 
сутність програми розширеного фінансування МВФ на наступний період, негативно впливає на інвестиційну привабливість України. Для інвесторів наявність програми Фонду навіть без самих траншів $є$ сигналом, що з позичальником можна працювати. Поки ж ані в МВФ, ані в інших кредиторів такої впевненості немає.

Якщо співпраця з МВФ припиниться, це стане ключовим макроекономічним ризиком для країни, попереджають в НБУ. В останньому звіті про фінансову стабільність аналітики банківського регулятора зазначають, що відсутність фінансової підтримки від міжнародних інститутів значно ускладнить рефінансування більш ніж 20 млрд дол. суверенного і гарантованого державою боргу. Поки ж в міжнародних резервах НБУ всього близько 18,4 млрд дол. Це суттєвий фактор ризику для будь-якого нового уряду, хто б його не очолив. 3 огляду на обсяг виплат і стан резервів Україні вже зараз варто почати переговори про запуск нової програми співпраці з МВФ, ще до завершення нинішньої в 2019 р., вважають в НБУ. Більше того, що наявність програми МВФ дозволяє країні, з якою працює Фонд, розраховувати на підтримку інших кредиторів - як Єврокомісії, так і Світового банку. їхні позики одні з найдешевших, які в принципі $€$ на ринку. За оцінками Мінфіну, в 2014-2016 рр. кредити від цих структур коштували лише 1-1,6\% річних. Тоді як євробонди Україна розміщувала під 7,375\%, а на внутрішньому ринку уряд займає вже під 16,5\% [2].

Як бачимо, розрахуватися з боргами, не беручи нові, влада вже не зможе, залишається дещо згладити піки виплат. Компенсувати нестачу зовнішнього фінансування Мінфін частково намагається за допомогою нерезидентів, для яких ставки за гривневими ОВДП на рівні 14,25-16,5\% річних є вигіднішими, ніж умови покупки боргів інших емітентів в Європі. До того ж іноземці, вкладаючи в держоблігації, можуть заробити на курсовій різниці. 3 початку цього року обсяг ОВДП в портфелі нерезидентів збільшився 35,1 млрд грн до 12,7 млрд грн. Приплив валюти від нерезидентів дозволив збити девальваційний тренд, коли курс вже перевищував 29 грн/дол. Втім поки цих вливань вкрай мало, щоб розраховувати на тривалу стабілізацію курсу і достатнє поповнення міжнародних резервів НБУ.

Саме тому важливо розробити систему стимулів для нерезидентів, які б спонукали до регулярної покупки українського боргу, а не покладатись лише на спекулятивний попит за рахунок високої ставки за паперами при вигідному валютному курсі. Найбільшою перепоною, на нашу думку $є$, складність процедури купівлі - українські ОВДП не обертаються в клірингових системах Euroclear i Clearstream. Тому нерезиденту, щоб купити ОВДП, потрібно оформити велику кількість паперів, перевести документи на українську, завести валюту в країну, продати ії на міжбанку, відкрити рахунок в цінних паперах в українського зберігача, підписати брокерський договір з українським торговцем тощо. Право інвесторів відкривати ра- 
хунок в депозитарії НБУ дещо покращить ситуацію. Проте, це зовсім не гарантує необхідну кількість ресурсу для погашення і обслуговування зовнішніх позик. Залучення більшого ресурсу від нерезидентів хоча і допоможе з рефінансуванням валютних ОВДП, але навряд чи дозволить отримати достатньо валюти для погашення єврооблігацій і розрахунків з МВФ.

Висновки. Для удосконалення структури боргу та його розміру було прийнято Програму управління державним боргом на 2017 р. та Стратегію реформування системи управління державними фінансами на 2017-2020 рр. [4]. До основних завдань управління боргом віднесено: підвищення стійкості державного боргу; створення умов для зниження частки державного боргу, номінованого в іноземній валюті, шляхом розвитку ринку облігацій внутрішньої державної позики, номінованих у національній валюті; розширення бази інвесторів у державні цінні папери [5].

В цілому, для підвищення ефективності боргової політики необхідно вжити наступні заходи:

-забезпечити подальше виконання заходів програми в рамках Механізму розширеного фінансування (EFF) України Міжнародним валютним фондом та зміцнення співпраці з іншими міжнародними фінансовими організаціями;

-вдосконалити боргову політику України та здійснити перехід до стратегічного управління державним боргом;

-законодавчо закріпити та забезпечити реалізацію середньострокової стратегії бюджетного планування та прогнозування;

-підвищити якість середньострокового економічного прогнозування та планування;

-посилити регулювання державного боргу в частині оптимізації співвідношення обсягів, структури, вартості та джерел його погашення шляхом законодавчого забезпечення еквівалентності бюджетно-податкових змін та запровадження боргових фіскальних правил як чинників оптимізації державних запозичень, зокрема, утримання балансу в емісійній діяльності та стягненні податків при нарощування боргу та збільшенні вартості його обслуговування;

-активізувати розвиток вітчизняного внутрішнього фінансового ринку як елементу цілісної фінансової системи та зниження вартості державних запозичень [5].

Крім того, з метою підвищення ефективності управління державним боргом необхідно створити умови для зниження частки державного боргу, номінованого в іноземній валюті, шляхом розвитку ринку облігацій внутрішньої державної позики, номінованих у національній валюті. Сприятиме цьому також розширення бази інвесторів у державні цінні папери, досягти якого можна за рахунок усунення бюрократичних та інших перешкод для інвестування нерезидентами 
в облігації внутрішньої державної позики, номіновані в національній валюті та укладання домовленостей з провідними європейськими депозитаріями щодо відкриття рахунка в депозитарії Національного банку.

Для розвитку первинного ринку державних цінних паперів та необхідно здійснити ряд заходів щодо підвищення ліквідності облігацій внутрішньої державної позики, включаючи розвиток інституту первинних дилерів та побудову кривої дохідності, яка слугуватиме орієнтиром для визначення дохідності решти інструментів.

Також, суттєвий вплив на державний борг має макроекономічне та бюджетне прогнозування, у рамках удосконалення якого необхідно: узгодити строки підготовки та перегляду макроекономічного прогнозу з бюджетним циклом у контексті середньострокового бюджетного планування, забезпечити неупередженість та деполітизацію цього процесу.

Важливо кроком покращення управління державним боргом $€$ перехід від короткострокового до середньострокового планування, на основі запровадження середньострокової бюджетної декларації, створення середньострокових рамок для планування, удосконалення інструментів прогнозування. Варто також посилити відповідальність суб'єктів законодавчої ініціативи та нормотворення за проведення оцінки впливу на бюджет нормативно-правових актів, підвищити рівень бюджетної дисципліни шляхом запровадження фіскальних правил та підвищити роль головних розпорядників бюджетних коштів у бюджетному процесі.

Необхідною умовою підвищення ефективності управління державним боргом є також розроблення та впровадження інформаційно-аналітичної системи для обробки даних щодо фіскальних ризиків, їх розмірів, розробки сценаріїв оцінки ймовірності їх виникнення, прогнозу очікуваного фіскального впливу, а також розробки заходів з їх мінімізації.

Таким чином, комплексне вирішення проблем зовнішнього державного боргу із урахуванням запропонованих заходів сприятиме зміцненню фінансової системи країни й посиленню стимулюючого впливу держави на соціально-економічний розвиток України.

1. Лісовенко В. В., Бенч Л. Я., Бец О. І. Державний борг: концептуальні засади та макроекономічні аспекти. Фінанси України. 2014. № 12. С. 7-31. 2. Статистичні матеріали щодо державного та гарантованого державою боргу України : Міністерство фінансів України. URL: https://index.minfin.com.ua/ua/finance/debtgov/ (дата звернення: 15.11.2018). 3. Сальникова Т. В. Державний борг України: оцінка та напрями підвищення ефективності управління. Економічний вісник університету. Переяслов-Хмельницький, 2017. Вип. 33(1). С. 385-394. URL: http://nbuv.gov.ua/UJRN/ecvu_2017_33\%281\%29_48 (дата звернення: 
15.11.2018). 4. Про затвердження плану заходів з реалізації Стратегії реформування системи управління державними фінансами на 2017-2020 роки : розпорядження Кабінету Міністрів України від 24 травня 2017 р. № 415-р. URL: http://zakon.rada.gov.ua/laws/show/415-2017-\%D1\%80 (дата звернення: 15.11.2018). 5. Про Стратегію національної безпеки України. Про рішення Ради національної безпеки і оборони України від 6 травня 2015 року : Указ Президента України від 26 травня 2015 року № 287/2015. URL: http://zakon5.rada.gov.ua/laws/show/287/2015. (дата звернення: 15.11.2018). 6. Fall F., Fournier J. Macroeconomic uncertainties, prudent debt targets and fiscal rules. OECD Economic Department Working Paper. July 2015.

\section{REFERENCES:}

1. Lisovenko V. V., Bench L. Ya., Bets O. I. Derzhavnyi borh: kontseptualni zasady ta makroekonomichni aspekty. Finansy Ukrainy. 2014. № 12. S. 7-31. 2. Statystychni materialy shchodo derzhavnoho ta harantovanoho derzhavoiu borhu Ukrainy : Ministerstvo finansiv Ukrainy. URL: https://index.minfin.com.ua/ua/finance/debtgov/ (data zvernennia: 15.11.2018). 3. Salnykova T. V. Derzhavnyi borh Ukrainy: otsinka ta napria-my pidvyshchennia efektyvnosti upravlinnia. Ekonomichnyi visnyk universytetu. Pereiaslov-Khmelnytskyi, 2017. Vyp. 33(1). S. 385-394. URL: http://nbuv.gov.ua/UJRN/ecvu_2017_33\%281\%29_48 (data zvernennia: 15.11.2018). 4. Pro zatverdzhennia planu zakhodiv z realizatsii Stratehii reformuvannia systemy upravlinnia derzhavnymy finansamy na 2017-2020 roky : rozporiadzhennia Kabinetu Ministriv Ukrainy vid 24 travnia 2017 r. № 415-r. URL: http://zakon.rada.gov.ua/laws/show/415-2017-\%D1\%80 (data zvernennia: 15.11.2018). 5. Pro Stratehiiu natsionalnoi bezpeky Ukrainy. Pro rishennia Rady natsionalnoi bezpeky i oborony Ukrainy vid 6 travnia 2015 roku : Ukaz Prezydenta Ukrainy vid 26 travnia 2015 roku № 287/2015. URL: http://zakon5.rada.gov.ua/laws/show/287/2015. (data zvernennia: 15.11.2018). 6. Fall F., Fournier J. Macroeconomic uncertainties, prudent debt targets and fiscal rules. OECD Economic Department Working Paper. July 2015.

Рецензент: к.е.н., професор Мельник Л. В. (НУВГП)

Kondratska N. M., Candidate of Economics (Ph.D.), Associate Professor, Dziuba V. I., Senior Student (National University of Water and Environmental Engineering, Rivne)

STATE DEBT OF UKRAINE: STRUCTURE, DYNAMICS AND DIRECTIONS OF ITS MINIMIZATION

In the article the dynamics and structure of public debt during the main periods of state development are analyzed. The expediency of allocating a new period - accelerated growth of the state boron is 
substantiated. Considerable attention is paid to the study of the public debt structure. It is pointed that foreign currency borrowing exceeds. The comparison of the main indicators with the limit values has confirmed the existence of significant debt security risks in Ukraine. The analysis revealed that in 2018-2019, the largest payments for public debt should be occurred. Thus, the government should reduce the ratio of debts in currency and hryvnia in the near future in order to minimize devaluation risks, as well as to enter foreign markets in order to refinance foreign currency debt.

The main tasks of debt management were pointed as: increasing the sustainability of public debt; creation of conditions for the share of public foreign currency debt reduction through the development of the market of domestic government bonds denominated in the national currency; increasing of the investor base in government securities. A number of measures aims the developing a public debt management system, including: the public debt structure optimization, the government securities market developing, macroeconomic and budgetary planning, forecasting, estimating and minimizing fiscal risks, were also substantiated.

Keywords: public debt; government loans; external borrowing; internal borrowing; debt policy; public debt structure.

Кондрацкая Н. Н., к.э.н., доцент, Дзюба В. И., студент (Национальный университет водного хозяйства и природопользования, г. Ровно)

\section{ГОСУДАРСТВЕННЫЙ ДОЛГ УКРАИНЫ: СТРУКТУРА, ДИНАМИКА И НАПРАВЛЕНИЯ ЕГО МИНИМИЗАЦИИ}

В статье проведен анализ динамики и структуры государственного долга в течение основных периодов развития государства. Обоснована целесообразность выделения нового периода - ускоренного роста государственного долга. Выделены основные угрозы в управлении государственным долгом и предложен ряд мер, направленных на развитие системы управления государственным долгом, среди которых: оптимизация структуры государственного долга, развитие рынка государственных ценных бумаг, макроэкономического и бюджетного планирования и прогнозирования, оценки и минимизации фискальных рисков.

Ключевые слова: государственный долг; государственные займы; внешние заимствования; внутренние заимствования; долговая политика; структура государственного долга. 